\title{
Central Bank Interest Rate Policy as a Pro-Crisis Instrument of Macroeconomic Regulation
}

\author{
Burenin Aleksey \\ Moscow State Institute of International Relations (University), Moscow, Russia
}

\begin{abstract}
Why does interest rate policy not work in the economy as economic theory suggests? To understand why, you need to look at the economy from a higher level of abstraction. With this approach, only two states of the economy can be distinguished. The first is a "normal" state; the second is crisis and recession. The "normal" state is the period after the recession and before the next crisis. During this period, the basic laws of the market economy work. During a crisis, the relationship between the level of interest rates and borrowing by households and businesses is broken. This explains the ineffectiveness of the policy of lowering interest rates. Different states of the economy have their own laws, and you cannot extrapolate tools that are successful under "normal" market conditions linearly to the crisis state of the economy. Why does the interest rate policy during the period of the "normal" state of the economy not adjust its development in order to prevent the onset of the crisis? Firstly, the conditions for the emergence of crisis phenomena are created by the interest rate policy at the very beginning of the business cycle, when central banks set and maintain low interest rates for a relatively long period. Secondly, by the end of the business cycle, the credit burden in economy reaches its maximum, so there is no further possibility of expanding effective demand by decreasing interest rates. Thirdly, interest rate policy is an instrument for rough adjustment of the economy, indiscriminately affecting all participants in economic relations. In an attempt to stimulate the economy, the central bank creates the conditions for increasing its imbalance. Fourth, at the end of the business cycle, the interest rate policy does not actually support the real economy, but only the stock market. Fifth, the Fed's policy has formed a pro-crisis conditioned reflex among market participants. Thus, central banks should leave the determination of the level of interest rates to the free market.
\end{abstract}

Keywords: interest rate policy, central bank, macroeconomic regulation

\section{Introduction}

One of the main tools of modern monetary policy of central banks is the interest rate. According to economic theory, its change allows you to influence the economic development of the country. To stimulate economic growth, it is necessary to lower the rate, i.e., make money cheaper so businesses and households can borrow more. To combat economic boom and inflation, the rate must be raised to make money more expensive and less accessible to borrowers.

The logic of this approach is impeccable, but does it work in life, as it seems in theory? Hardly always. Otherwise, successful regulation of the economy would not have been difficult, especially taking into account 
the experience of the Fed over a hundred-year period of existence. The most sad thing is that the policy of interest rates does not work properly just at the moments when the most tangible results are required from it, namely, during periods of economic crisis. Moreover, we argue that the interest rate policy of central banks is pro-crisis, namely, it creates conditions that inevitably lead to the onset of economic crises.

\section{Findings}

Within the framework of modern theory, a possible explanation of the not always successful results of the interest rate policy could be explained by the fact that the rate set by the central bank does not always correspond to the natural rate of interest. For example, as Roger W. Garrison notes, according to economists of virtually all stripes between mid-2003 and mid-2004, the Fed's target rate was "too low for too long" relative to the natural rate (2012, p. 433). Then it turns out that central banks, setting a rate not equal to the natural rate of interest in order to maintain macroeconomic stability, tread on the same rake each time, since such a policy so far has not made it possible to avoid the main economic problem of capitalism, namely, economic crises. As Roger W. Garrison notes, "The sustainability that the Federal Reserve has actually achieved is strictly (and perversely) an inter crises sustainability" (2012, p. 424). At the same time, there is no guarantee that if the policy of the central bank follows the natural rate of interest, the economy will be able to avoid economic crises.

To try to understand the reason for the failure of the interest rate policy in the fight against crises, you need to look at the economy, rising to a higher level of abstraction. With this approach, only two states of the world can be distinguished in the economy. The first is a "normal" state. It characterizes the period of development after the recession and before the next crisis. It is "normal", because during this period the basic laws of the market economy, described in textbooks, including the relationship between the interest rate and the demand for money from business and households, work. Therefore, if the central bank lowers interest rates, businesses and households will begin to borrow more actively, and GDP growth will accelerate. If the bank raises the rate, this will prevent the increase in new loans and GDP growth. The results will be determined by the decrease or increase in the interest rate by the central bank. However, during the crisis, the state of the economy changes in the sense that the above-noted relationship between the level of interest rates and borrowing by households and businesses is violated. The willingness of banks to lend to households and businesses in the face of increased risks decreases. This explains the inefficiency of the policy of reducing interest rates by central banks during the crisis. A striking example of such a situation was the results of monetary policy during the crisis of 2007-2008 and the subsequent Great Recession. As Robert Heller notes, "the Fed's low interest rate policy have been ineffective in raising economic growth" (2017, p. 259). The fact is that central banks tried to achieve stabilization and economic growth with the help of tools that no longer work in the crisis conditions or have poor efficiency. Thus, different states of the economy have their own laws, and it is impossible to directly use the tools that are successful under "normal" market conditions to the crisis state of the economy. This view can be proved by the appearance in economic theory of such schools as Keynesianism and Monetarism, which de facto recognized that there are two qualitatively different states of the economy that are described by their own laws (Burenin, 2019). The fact that the market is in a "normal" state most of the time has shaped the view among economists that by changing the interest rate it is possible to effectively influence the economy in any conditions, including in a crisis.

One may ask why the interest rate policy, which is carried out during the period of the "normal" state of the economy and when it really has the potential to effectively influence the economy, does not correct its 
development in order to smooth out fluctuations in the business cycle and prevent the formation of conditions for the next crisis. The answer to it is that the interest rate policy inherently has a pro-crisis characteristic, i.e., it does not prevent, but each time pushes the economy towards another economic crisis. It is important to emphasize the following.

Firstly, the conditions for the emergence of a future crisis are created by the interest rate policy at the very beginning of the business cycle, when central banks, in an effort to stimulate business activity, establish and maintain low interest rates for a relatively long period. Touching on this issue, the Austrian school business cycle theory directly indicates that "the business cycle is caused by a reduction of the interest rate below its natural level", resulting in "malinvestment" (Saravia, 2014. p. 182). With a subsequent increase in interest rates by central banks, they turn out to be unprofitable.

Secondly, the main cause of the crisis is a decrease in effective demand over supply in the economy. Demand is primarily generated by households and businesses. However, a substantial part of it is represented by credit resources. By the end of the business cycle, the credit burden of businesses and households reaches its maximum; therefore, there are no further opportunities to expand effective demand. In the future, one can expect its stabilization at best, and its decline at worst. At this point, central banks lower interest rates in an attempt to make credit cheap and stimulate demand. However, with total over-lending, even a very low rate is not able to increase borrowing at the scale necessary to continue economic growth. It can only support the demand for credit for a short time.

We would like to note that the past business cycle proceeded without a crisis since 2008 and exceeded the duration of most business cycles of the previous periods. How can this situation be explained? In our opinion, this is due to the fact that, "fortunately for the economy", the monetary policy of the central banks proved to be ineffective and did not actively influence the growth of the credit load in the economy. Commercial banks refrained from widespread lending to the economy, despite large-scale QE programs to increase liquidity in the economy. This is clearly seen from Figure 1, which shows the debt of US households for the period from 1999 to the second quarter of 2019. If during the previous cycle, it increased from 4.76 trillion dollars in 1999 to 12.67 trillion dollars in 2008; then from 2008 to 2012 it dropped to 11.34 trillion dollars. Debt began to grow again from 2013 and in the 2nd quarter of 2019 reached only 13.86 trillion dollars. Thus, throughout the entire past economic cycle, household debt remained practically at the same level.

Thirdly, the policy of interest rates, as it is currently applied, is an instrument of crude economic adjustment that applies to all participants in economic relations. However, different sectors of the economy have different sensitivity to the interest rate and, therefore, do not receive the same stimulating effect. As Claudio Borio-Head of the Monetary and Economic Department at the Bank for International Settlements-notes: "After all, the interest rate is bound to affect different sectors differently, resulting in different rates of capital accumulation and various forms of hysteresis" (2019, p. 287). As a result, in an attempt to stimulate the economy, the central bank ultimately contributes to its imbalance.

Fourth, at the final stage of the business cycle, the interest rate policy is no longer able to support the real economy, and in fact affects only the stock market. Such a conclusion can be made if we agree with the fact that, as J. M. Keynes noted, the actions of entrepreneurs are determined by the state of their "animal spirit". Consequently, lower interest rates are intended to stimulate entrepreneurial optimism. However, patterns of past periods suggest that on average, the duration of the business cycle is about 10 years. In this regard, it is hardly possible to instill confident optimism in the "animal spirit" of entrepreneurs after such a period of time by simply 
lowering the rate. At the same time, the "speculative spirit" of the stock market immediately comes alive with such actions by central banks. In addition, he looks forward to them and for some time keeps the stock market afloat. Thus, assessing the effectiveness of the monetary policy of the Fed to combat the crisis of 2007-2008 and its consequences, Miki Levy notes that: "The Fed's sustained low policy rate, quantitative easing (QE) ... have stimulated financial markets and boosted asset prices but have failed to stimulate the economy" (2017, p. 39).

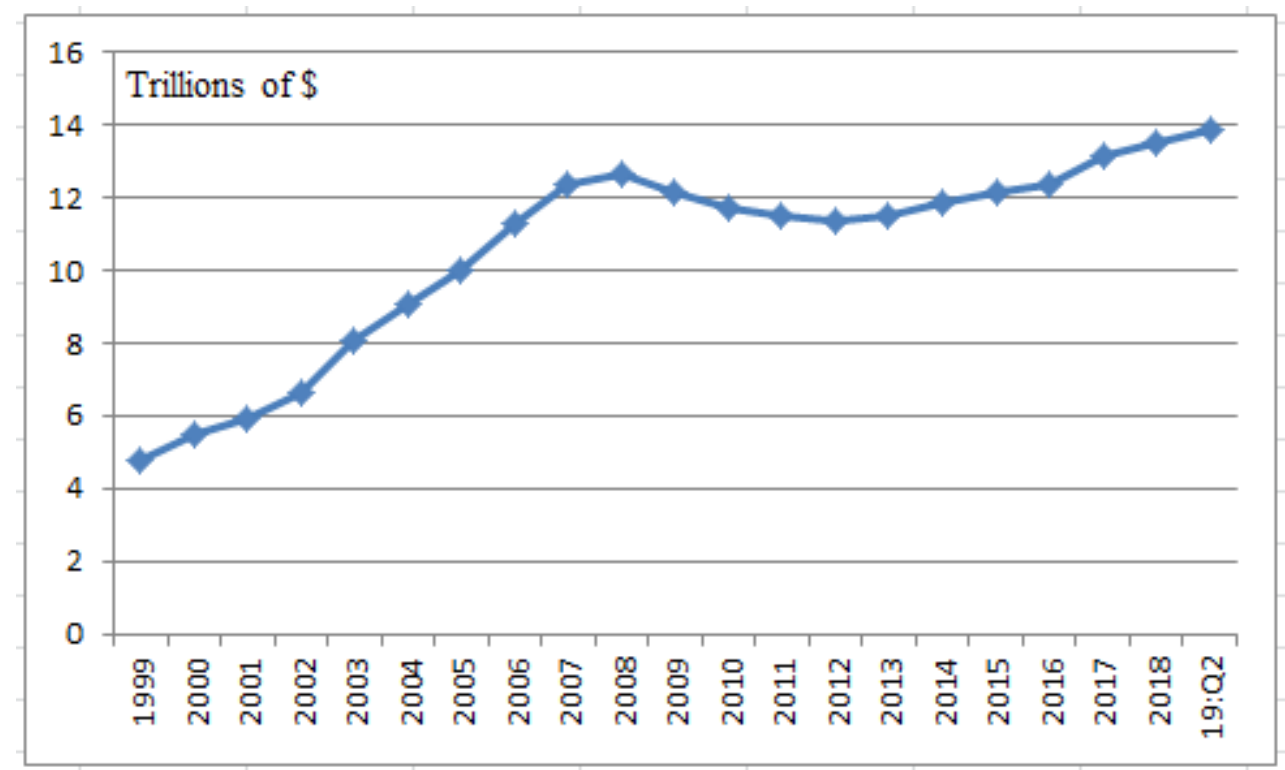

Figure 1. U.S. household debt from 1999 to Q2 2019.

Sources: Quarterly Report on Household Debt and Credit, August 2019, p. 3, Federal Reserve Bank of New York, Quarterly Report on Household Debt and Credit, Historical (pre-2003) Data, Federal Reserve Bank of New York.

Fifth, considering the interest rate policy of the Fed in historical retrospect, it can be noted that it has formed, at least for some of the stock market participants, a kind of pro-crisis conditioned reflex. For example, according to John Lynch, chief investment strategist for LPL Financial, "the economy typically slips into a recession four years after the first Federal Reserve rate hike" (2018, p. 49). Naturally, such a statistical regularity preconfigures the participants in the stock market for a pessimistic mood and the corresponding actions, taking into account the indicated point in time. Similarly, the very fact that the Fed started lowering its rate after a round of ups also forms a pro-crisis mood. Up to this point, markets are only speculatively supported by hopes for its future decline. In this regard, we cite the words of Mike Wilson, chief U.S. equity strategist at Morgan Stanley. Considering the situation on the stock market at the end of August 2019, after the Fed at its meeting in July 2019 for the first time lowered the target rate on federal funds, he noted that "The Fed put $^{1}$ basically expired when they cut rates. The hope of Fed cuts has been propping up the markets all year, but rate cuts aren't good for the market if you're going into recession" (Matthews, 2019). Thus, the beginning of the rate cut can be interpreted as a signal to society that the upstream part of the business cycle has come to an end and it is necessary to prepare for the crisis and recession. Subsequent Fed rate cuts only strengthen that confidence. It turns out that at the end of the business cycle, a decrease in the rate ultimately has the opposite effect to the desired one, and rather acts depressing on the entrepreneurial mood than stimulates optimism and

\footnotetext{
${ }^{1}$ Put Fed means market support from the Fed. This uses the analogy of the put option, which gives its owner the right to sell the financial asset at a predetermined price. Put options are used as insurance against a possible depreciation of a financial asset.
} 
the desire to make new investments, although for some time such actions allow speculatively keeping the stock market afloat. This creates the illusion that things are not going bad in the economy. Why do we use the word "illusion"? It is because it is believed that the stock market is a sensitive barometer of the state of affairs in the economy and pre-signals a subsequent economic downturn. As Paul J. Lim notes,

The average bear market, in fact, has typically begun $7 \frac{1}{2}$ months prior to the start of an official recession, according to CFRA $^{2}$. Sometimes the lag time is even greater. The 2000-2002 bear market began a full year before the economy officially slid into a recession. (2018, p. 49)

\section{Conclusions}

When the "animal spirit" of entrepreneurs is strong, the economy does not need doping from low interest rates, since it creates the conditions for an excessive increase in the credit burden of households and businesses and ultimately leads to an imbalance in the economy. When the entrepreneurial spirit is pessimistic, then, as experience has repeatedly shown, a policy of low interest rates is not able to properly stimulate business. Therefore, central banks should leave the determination of the level of interest rates to the free market. In this regard, we share the criticism of central banks expressed by K. Dowd and M. Hutchinson that banks are considering the interest rate and money supply not "as the products of markets but as control instruments to be determined by some central authority" (2017, p. 304).

As we see, to date, this approach has not allowed avoiding economic crises and recessions, and in the hands of central banks, the policy of interest rates, on the contrary, has acquired a pro-crisis character.

\section{References}

Burenin, А. Н. (2019). Пределы макроэкономической политики под углом зрения экономических кризисов (The limits of macroeconomic policy under the eye of economic crisis). Экономическая Политика (Economic Policy), 14(1), 76-91.

Borio, C. (2019). On money, debt, trust, and central banking. Cato Journal, 39(2), 267-302.

Dowd, K., \& Hutchinson, M. (2017). From excess stimulus to monetary mayhem. Cato Journal, 37(2), 303-328.

Federal Reserve Bank of New York. (pre-2003). Quarterly report on household debt and credit, historical.

Federal Reserve Bank of New York. (August 2019). Quarterly report on household debt and credit.

Garrison, R. W. (2012). Natural rates of interest and sustainable growth. Cato Journal, 32(2), 423-437.

Heller, R. (2017). The financial crisis: Monetary mischief and the debt trap. Cato Journal, 37(2), 247-261.

Levy, M. (2017). Why have the Fed's policies failed to stimulate the economy? Cato Journal, 37(1), 39-45.

Lim, P. J. (2018). 3 ways this bull market could end. Money.com January/February, p. 47-51.

Matthews, C. (2019). Stocks could fall another $8 \%$ as "Trump put" and "Fed put" expire, says Morgan Stanley's Mike Wilson. Retrieved from https://www.marketwatch.com/story/the-fed-trump-puts-have-expired-says-morgan-stanleys-mike-wilson-leaving-stocks-vul nerable-to-another-8-decline-2019-08-19

Saravia, J. A. (2014). Merger waves and the Austrian business cycle theory. The Quarterly Journal of Austrian Economics, 17(2), 179-196.

${ }^{2}$ CFRA is one of the world's largest independent research firms. 